\title{
Recently isolated lycodine-type Lycopodium alkaloids and their total synthesis: a review
}

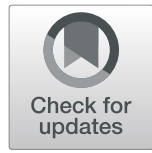

Shriniwas P. Patil[

\begin{abstract}
Background: Since long back, several plants species belonging to family Lycopodiaceae or Huperziaceae are being traditionally used in treatment of diseases like Alzheimer's disease and myasthenia gravis. In 1986, huperzine A, structurally lycodine type of alkaloid was isolated and established as potent acetylcholine esterase inhibitor. Hence, further, in pursuit of similar compounds, several hundreds of different types of lycopodium alkaloids have been isolated from different Lycopodiaceae or Huperziaceae plants species.

Main body: For few of these recently isolated alkaloids, the possible mechanisms of their biosynthesis have been proposed while few of them were tried for their laboratory total asymmetric synthesis. This review summarized lycodine-type Lycopodium alkaloids, whose isolation, biosynthesis, and total synthesis have been reported after 2000. It also includes structure-activity relationship.
\end{abstract}

Short conclusion: More than 40 lycodine-type alkaloids have been isolated and structurally elucidated since 2000. Their biosynthetic pathway suggested that they got biosynthesized from lysine, while structure-activity relationship established the structural requirement of lycodine-type alkaloids to possess potent acetylcholine esterase inhibitory activity.

\section{Background}

Lycopodium alkaloids with unique heterocyclic frameworks of different types like $\mathrm{C}_{11} \mathrm{~N}, \mathrm{C}_{15} \mathrm{~N}, \mathrm{C}_{16} \mathrm{~N}, \mathrm{C}_{16} \mathrm{~N}_{2}, \mathrm{C}_{22} \mathrm{~N}_{2}$, or $\mathrm{C}_{27} \mathrm{~N}_{3}$ have gained enormous research interest with focus on their biogenesis [1-3] and biological activities [4]. As per Ayer et al. 1991, lycopodium alkaloids are of four types: lycodine-type, lycopodane-type, fawcettimine-type, and miscellaneous-type [5]. The lycodine group consists of two nitrogens in structure containing a pyridine, anpyridone, or a hydrogenated pyridine ring.

Investigations on lycopodium alkaloids was started in 1881, when Bodekar first lycopodium alkaloid, lycopodine from Lycopodium complanatum [6]. Then, in 1938, Achmatowicz and Uzieblo again isolated lycopodine with correct molecular formula, and also two new nitrogencontaining compounds [7]. In the middle of twentieth century, Canadian Scientist, W.A. Ayer made significant

Correspondence: patilsp111@gmail.com

Department of Pharmacognosy, SCES's Indira College of Pharmacy, Pune 411 038 , India
Springer Open

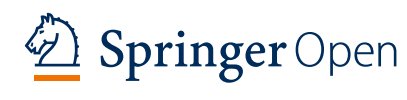

contribution in isolation of various alkaloids from lycopodium species and publishing research articles and reviews to make his findings open in public domain. During the same time, in 1944, Rothmaler re-established the taxonomy of Huperzia plant by separating it from family lycopodiaceae and placing into Huperziaceae or Urostachyaceae, which comprised of around 150 species of two genera, Huperzia and Phlegmariurus [8]. This taxonomic system has been supported by chemotaxonomic analysis made time to time in upcoming future. During the early 1980s, Chinese researchers screened Lycopodium species for new entity that could be used for treatment of myasthenia gravis [9]. The lycopodium alkaloid research was at peak in 4 years period of 19861990, when few lycopodium alkaloids with potentacetylcholinesterase inhibition activity were isolated. In 1986, Chinese scientist Liu and his co-workers isolated huperzine A from the plant Qian Ceng Ta (included in Chinese folk medicine) Huperzia serrata (Thunb.ex Murray) Trev.) was found to be most potent acetylcholinesterase inhibitor [10, 11]. Reported learning and

(c) The Author(s). 2020 Open Access This article is licensed under a Creative Commons Attribution 4.0 International License, which permits use, sharing, adaptation, distribution and reproduction in any medium or format, as long as you give appropriate credit to the original author(s) and the source, provide a link to the Creative Commons licence, and indicate if changes were made. The images or other third party material in this article are included in the article's Creative Commons licence, unless indicated otherwise in a credit line to the material. If material is not included in the article's Creative Commons licence and your intended use is not permitted by statutory regulation or exceeds the permitted use, you will need to obtain permission directly from the copyright holder. To view a copy of this licence, visit http://creativecommons.org/licenses/by/4.0/. 
memory-enhancing properties and pharmacological application of huperzine A in Alzheimer's disease and myasthenia gravis actually initiated the new tide of lycopodium alkaloid research. Now, as per our literature survey, since 2000, only few (14 out of 500+) species of plants belonging to family either lycopodiaceae or huperziaceae have been processed for isolation of active lycodine type of lycopodium alkaloid.

\section{Main text}

Biological significance and need of isolation of new Lycopodium alkaloids

Since long back, several traditional Chinese medicinal plants of family Lycopodiaceae and Huperziaceaeare being used in treatment of sprains, strains and myasthenia [12]. Advanced phytochemical analysis and pharmacological screening revealed that lycopodium alkaloids present in these plants have potential acetylcholinesterase (AChE) inhibitory activity and thereby therapeutic application in treating Alzheimer's disease $[4,13]$.

In order to meet increasing global demands for promising remedy on acetylcholine-dependent autonomic nervous system diseases, several attempts have been made for total synthesis of potent and biologically safe lycopodium alkaloids. But it was observed that a polycyclic carbon skeleton with different levels of oxidation is the common feature in all Lycopodium alkaloids, posing the challenging target for total synthesis [33-35].

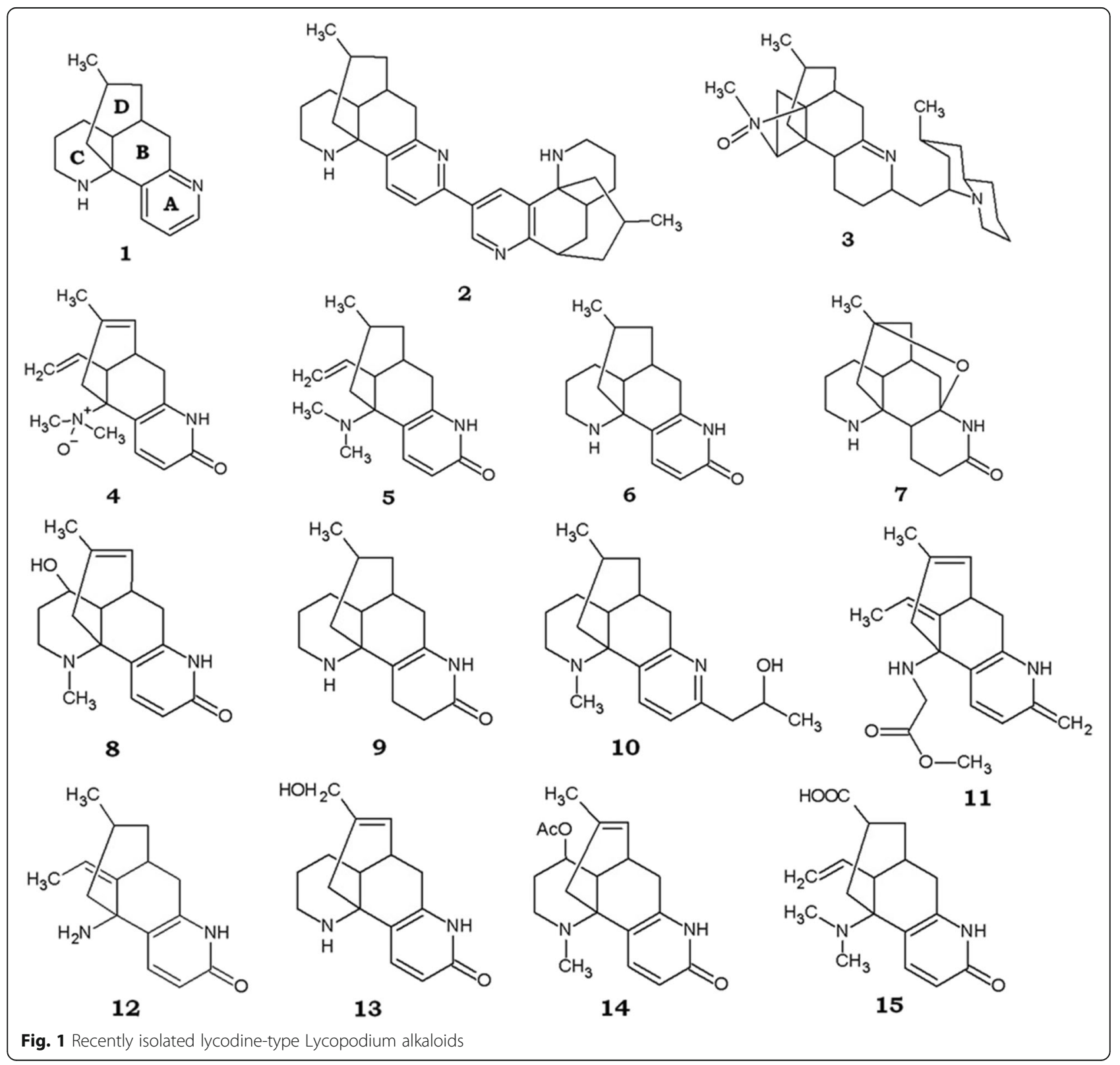


Hence, in pursuit of potent acetylcholinesterase (AChE) inhibitory lycopodium alkaloids, researcher so far continued their efforts in isolation and structural elucidation of novel lycopodium alkaloids. This review consists of comprehensive data of newly isolated and pharmacologically screened Lycodine-type of lycopodium alkaloids, reported since 2000 (Figs. 1, 2, and 3; Table 1).

\section{Extraction and isolation of lycodine type Lycopodium} alkaloids

Isolation of lycodine-type Lycopodium alkaloids involves alcoholic extraction of plant material and column chromatographic separation using suitable combination of stationary and mobile phase. For this, fresh or air-dried powdered material of aerial part or whole plant of any selected club moss species is firstly, extracted, mostly with methanol (occasionally with ethanol). This alcoholic extract is then concentrated in vacuum and 3\% tartaric acid is added to it. Then, in order to remove non-alkaloid components, it is partitioned with ethyl acetate and polar fraction is made alkaline with sodium carbonate or sodium bicarbonate or sodium hydroxide, potassium carbonate or ammonia water. Due to alkaline nature and presence of lone of electrons on nitrogen, alkaloidal contents remain unionized. Further,

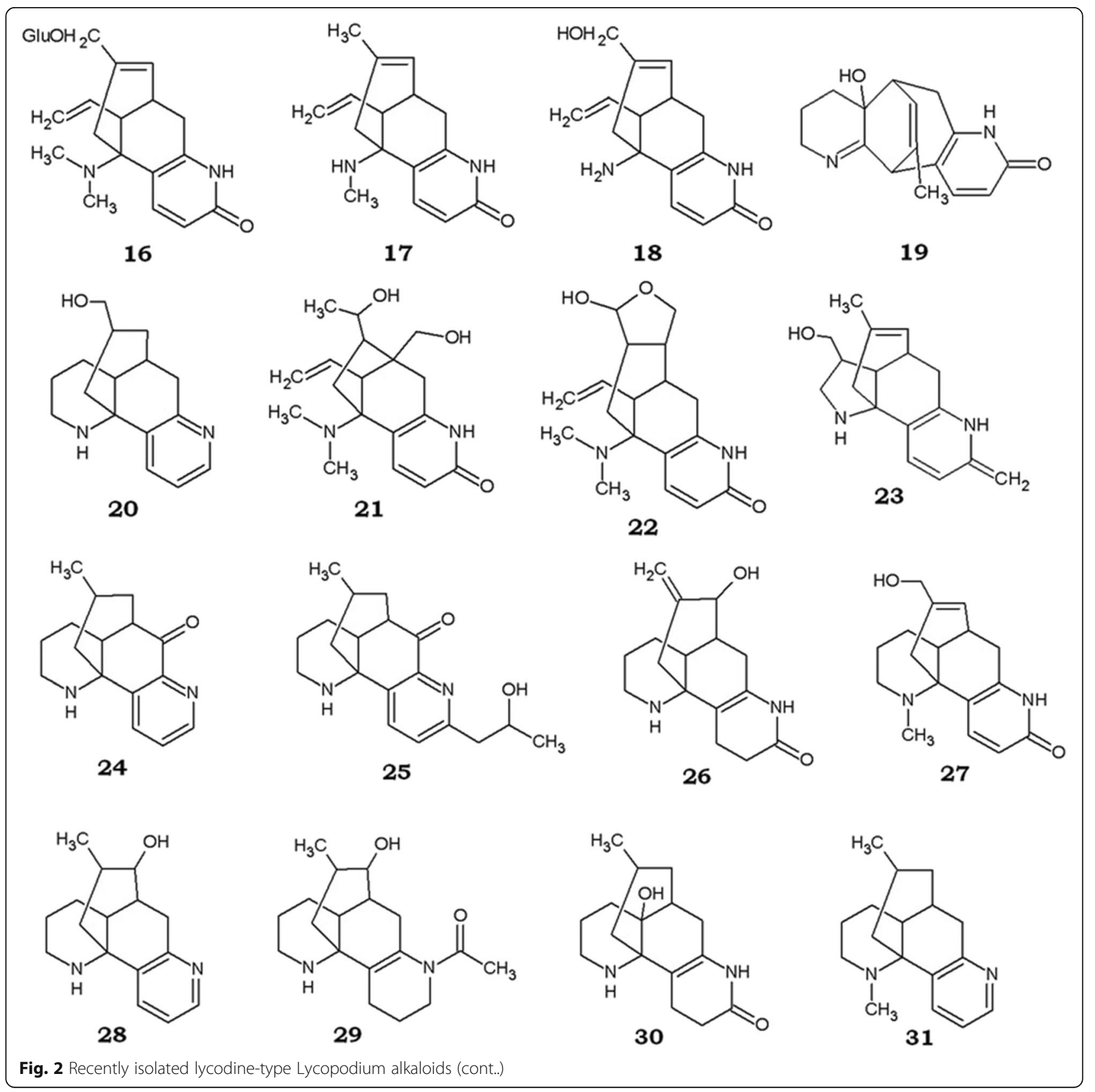


<smiles>CC1=CC2Cc3[nH]c(=O)ccc3C(N(C)C)(C1)C2CO</smiles>

32<smiles>CC1=CC2Cc3[nH]c(=O)ccc3C3(CNCC(O)C3)C2C1</smiles>

36<smiles>CN1CCC(O)C2C3Cc4[nH]c(=O)ccc4C4(CC(CO)=CC24)C31</smiles><smiles>C=CC1C(C)C(O)C2C1Cc1[nH]c(=O)ccc1C2(C=C)N(C)C</smiles>

33<smiles>C=C1CC2C(Cc3[nH]c(=O)ccc3C23CCCCC3O)C1O</smiles>

37<smiles>CC1CC2Cc3ncc(C4CCCCN4)cc3C3(CCCNC3)C2C1</smiles>

41<smiles>C=CC1C2Cc3[nH]c(=O)ccc3C3(N)CCC(CO)CC3CC12</smiles>

34<smiles>CC1CC2C(Cc3[nH]c(=O)ccc3C23CCCCN3)C1O</smiles>

38<smiles>C=CC1C(C)CC2(N)C3=C(CC12)NC(=O)CC3</smiles><smiles></smiles>

35<smiles>CC1CC2C(O)(Cc3[nH]c(=O)ccc3C23NCCCC3C)C1</smiles>

39<smiles>CC1CC2CC3=C(CCC(=O)N3)C3(CCCNC3)C2(O)C1</smiles>

43

Fig. 3 Recently isolated lycodine-type Lycopodium alkaloids (cont..)

alkaloids are extracted from this alkaline system using dichloromethane or chloroform, which are further dried over anhydrous sodium sulfate. Concentrated dichloromethane or chloroform soluble semi dried, viscous portion ischromatographed over silica gel, Sephadex LH-20 or Mitsubhishi Chemical Ion exchange resins eluted with a varying combination of solvents, based on either increase or decrease in polarity of mobile phase. In few cases, preparative HPLC is used for even fine separation. The compound isolated is further structurally elucidated using advance techniques and evaluated for (AChE) inhibitory activities.

\section{Screening of lycodine type Lycopodium alkaloids for acetylcholinesterase (AChE) inhibitory activity}

For most of the newly isolated and structurally elucidated lycopodium alkaloids, acetylcholinesterase (AChE) inhibitory potential was determined according to the method using human RBC membranes as described by Ellman et al. 1961 with few modifications [36].

Briefly, the isolated compounds were diluted with buffer. Then, to each well of 96-well microplate, test sample was added together with acetylthiocholine iodide (ATCI), 5,5dithiobis(2-nitrobenzoic acid) (DTNB) and acetylcholinesterase (AChE) enzyme in distilled water or buffer $\mathrm{pH}$ 7.4 to 8 .

These solutions isolated compounds were used to determine their $\mathrm{IC}_{50}$. Huperzine A [31], physostigmine salicylate [37], tacrine [38], or galanthamine [39] was used as positive control. Determinations were carried out by tracking the formation of the 5-thio-2-nitrobenzoate anion at $405 \mathrm{~nm}$, after $30 \mathrm{~s}$ cycle, for $3 \mathrm{~min}$ and then the reaction mixtures were incubated at 
Table 1 Recently isolated lycodine type Lycopodium alkaloids and theiracetylcholinesterase (AChE) inhibitory activity

\begin{tabular}{|c|c|c|c|}
\hline Lycopodium alkaloid & Plant spp. & $\mathrm{LC}_{50}$ & Reference \\
\hline Complanadine A (2) & Lycopodium complanatum & - & {$[14]$} \\
\hline Himeradine A (3) & Lycopodium chinense & - & {$[15]$} \\
\hline Huperzinine $\mathrm{N}$-oxide (4) & \multirow{2}{*}{$\begin{array}{l}\text { Lycopodium } \\
\text { casuarinoides }\end{array}$} & - & \multirow[t]{2}{*}{ [16] } \\
\hline 8,15-dihydrohuperzinine (5) & & - & \\
\hline N-demethyl-obscurine (6) & \multirow[t]{2}{*}{ Lycopodium serratum } & - & \multirow[t]{2}{*}{ [17] } \\
\hline Lycodine (1) & & - & \\
\hline Casuarine A (7) & \multirow{2}{*}{$\begin{array}{l}\text { Lycopodium } \\
\text { casuarinoides }\end{array}$} & - & \multirow[t]{2}{*}{ [18] } \\
\hline Casuarine B (8) & & $46.4 \mu \mathrm{M}$ & \\
\hline N-demethyl-sauroxine (9) & Huperziasaururus & - & [19] \\
\hline N-methylhydroxypropyllycodine (10) & Lycopodium japonicum & - & {$[20]$} \\
\hline Huperserine $E(\mathbf{1 1})$ & Huperzia serrata & $6.71 \mu \mathrm{M}$ & [21] \\
\hline 8,15-dihydrohuperzine A (12) & Huperziacarinata & $2.6 \mu \mathrm{M}$ & [22] \\
\hline 16-hydroxyhuperzine B (13) & \multirow[t]{6}{*}{ Lycopodiastrumcasuarinoides } & $87.3 \mu \mathrm{M}$ & \multirow[t]{6}{*}{ [23] } \\
\hline N-methyl-11-acetoxyhuperzine B (14) & & - & \\
\hline 8,15-dihydrolycoparin A (15) & & - & \\
\hline (7S,12S, 13R)-huperzine D-16-O- $\beta$-D-glucopyranoside (16) & & - & \\
\hline N-demethylhuperzinine (17) & & $1.9 \mu \mathrm{M}$ & \\
\hline Lycoparin C (18) & & $23.9 \mu \mathrm{M}$ & \\
\hline N-methylhydroxypropyllycodine (10) & Lycopodium japonicum & - & [24] \\
\hline Phlefargesiine A (19) & Phlegmariurusfargesii & - & [25] \\
\hline 16-hydroxylycodine (20) & Phlegmariurushenryi & - & [26] \\
\hline Lycocasuarine A (21) & \multirow{3}{*}{$\begin{array}{l}\text { Lycopodiastrum } \\
\text { casuarinoides }\end{array}$} & $>100 \mu \mathrm{M}$ & \multirow[t]{3}{*}{ [27] } \\
\hline Lycocasuarine B (22) & & $>100 \mu \mathrm{M}$ & \\
\hline Lycocasuarine C (23) & & $7.4 \mu \mathrm{M}$ & \\
\hline lycoannotine G (24) & \multirow[t]{2}{*}{ Lycopodium annotinum } & - & \multirow[t]{2}{*}{ [28] } \\
\hline lycoannotine H (25) & & - & \\
\hline Lycofargesiine A (26) & \multirow[t]{4}{*}{ Huperziafargesii } & - & \multirow[t]{4}{*}{ [29] } \\
\hline Lycofargesiine B (27) & & - & \\
\hline Lycofargesiine C (28) & & $8.63 \mu \mathrm{M}$ & \\
\hline Lycofargesiine D (29) & & - & \\
\hline 12a-hydroxy-N-demethyl-sauroxine (30) & \multirow[t]{3}{*}{ Phlegmariurussaururus } & $33.8 \mu \mathrm{M}$ & \multirow[t]{3}{*}{ [30] } \\
\hline N-methyllycodine (31) & & $547.5 \mu \mathrm{M}$ & \\
\hline N-demethyl-sauroxine (9) & & $1.38 \mu \mathrm{M}$ & \\
\hline Lycocasuarine I (32) & \multirow{9}{*}{$\begin{array}{l}\text { Lycopodiastrum } \\
\text { casuarinoides }\end{array}$} & $>200 \mu \mathrm{M}$ & \multirow[t]{9}{*}{ [31] } \\
\hline Lycocasuarine J (33) & & $>200 \mu \mathrm{M}$ & \\
\hline Lycocasuarine K (34) & & $171.9 \mu \mathrm{M}$ & \\
\hline Lycocasuarine L (35) & & $>200 \mu \mathrm{M}$ & \\
\hline Lycocasuarine M (36) & & $97.2 \mu \mathrm{M}$ & \\
\hline Lycocasuarine N (37) & & $112.1 \mu \mathrm{M}$ & \\
\hline Lycocasuarine $O$ (38) & & $137.8 \mu \mathrm{M}$ & \\
\hline Lycocasuarine P (39) & & $127.8 \mu \mathrm{M}$ & \\
\hline Lycocasuarine Q (40) & & $>200 \mu \mathrm{M}$ & \\
\hline Lycoplatyrine A (41) & \multirow{3}{*}{$\begin{array}{l}\text { Lycopodium } \\
\text { platyrhizoma }\end{array}$} & $>30 \mu \mathrm{M}$ & \multirow[t]{3}{*}[32]{} \\
\hline Lycoplatyrine B (42) & & $>30 \mu \mathrm{M}$ & \\
\hline Lycoplanine D (43) & & - & \\
\hline
\end{tabular}




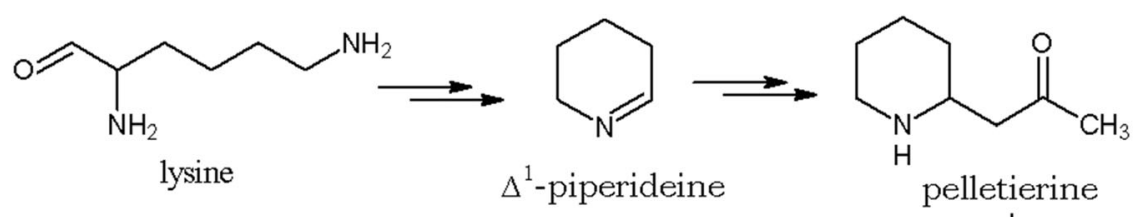<smiles>C=CC1C2(CO)Cc3[nH]c(=O)ccc3C1(CO)C(C)(O)C2(C)C</smiles>

lycocasuarine A<smiles>C=CC</smiles><smiles>C=C</smiles><smiles>C=CC1C2Cc3[nH]c(=O)ccc3C1(N(C)C)CC21CCCC1</smiles>

lycocasuarine B<smiles>CC1=CC2Cc3[nH]c(=O)ccc3C3(C2)NCC(CO)CC13</smiles>

lycocasuarine $\mathrm{C}$<smiles>CC1CC(CC2CCCCN2)C2C3CCC(C3)C12</smiles>

phlegmarine
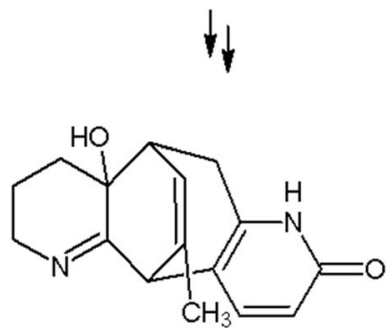

phlefargesiine A

Fig. 4 Possible biosynthetic pathway for lycodine-type Lycopodium alkaloids<smiles>C=CC1=CCCCN1C(=O)OCc1ccc(O)c(C(=O)/C=C/C(=O)OCC)n1</smiles><smiles>CCOC(=O)C1CC=C2C(CCCN2C(=O)OCc2ccccc2)C1C(=O)c1ncccc1O[Tl]</smiles>

Fig. 5 Total synthesis of lycodine 
room temperature for 20 to $30 \mathrm{~min}$. After lapse, the absorbances were recorded again in identical way. The inhibitory percentage of each sample was calculated based on the absorbance $(A)$ of the blank $\left(A_{0}\right)$ and the test compound $\left(A_{1}\right)$ using the following equation:

$$
\text { Inhibition }(\%)=\left(1-\mathcal{A}_{1} / \mathcal{A}_{0}\right) \times 100 \text {. }
$$

Results were analyzed by using software like GraphPad Prism 6 and thus, the $\mathrm{IC}_{50}$ obtained.

\section{Structure of lycodine-type Lycopodium alkaloids and their AChE inhibitory activity relationship}

In many cases, huperzine A was used as positive control; therefore, comparison of $\mathrm{LC}_{50}$ values of new alkaloids with that of huperzine A $(0.17 \mu \mathrm{M},[31])$ could be made, as a function of potency; thereby their structure-activity relationship could be explained. The higher the $\mathrm{LC}_{50}$ value, the lower is the potency and vice versa.

Compound 9 with no double bond between $\mathrm{C}-8$ and $\mathrm{C}-16$, ketone group at $\mathrm{C}-1$, and double bond between $\mathrm{C}$ 4 and $\mathrm{C}-5$ had less $\mathrm{LC}_{50}$ value. Cleavage of C-ring and ketone group at $\mathrm{C}-1$, as found in compounds $11,12,17$, and 18, exhibited potency close to that of huperzine A. Replacement of six-membered C-ring of lycodine structure by five-membered nitrogen ring, as in compound 23, have shown lesser $\mathrm{LC}_{50}$ value meaning higher potency. Compound 28 represented potency nearly equal to that of huperzine A, may be due to hydroxyl group at C-8. Compound 41 was lycodine structure substituted with a piperidine moiety at $\mathrm{C}-2$ and exhibited moderate activity. N-methylation of lycodine decreased the activity.

\section{Plausible biogenesis of lycodine-type Lycopodium alkaloids}

For few of the newly isolated lycodine-type lycopodium alkaloids, a plausible biogenetic pathway has also been proposed. On detail literature survey, it was found that, in all cases, biogenesis starts with amino acid, lysine, proceeds through sequential formation of intermediates like pelletierine, $\Delta^{1}$-piperideine, phlegmarane skeleton, and lycodoline-type skeleton compounds, which by several reactions like oxidation, cyclization, Polonovski-type reaction, Michael type reaction, and Wagner-Meerwein rearrangement; finally, converted to final lycodine-type lycopodium alkaloids. Liu et al. 2013 quoted a plausible biogenetic pathway for casuarine A according to which des-N-methyl-a-obscurine underwent an oxidation to produce intermediate, followed then by an addition in the acidic conditions to afford another intermediate, which underwent tautomerism and a cyclization to yield casuarine A [18]. As per Meng et al. 2016, phlefargesiine A could be either derived from a lycodine-type precursor

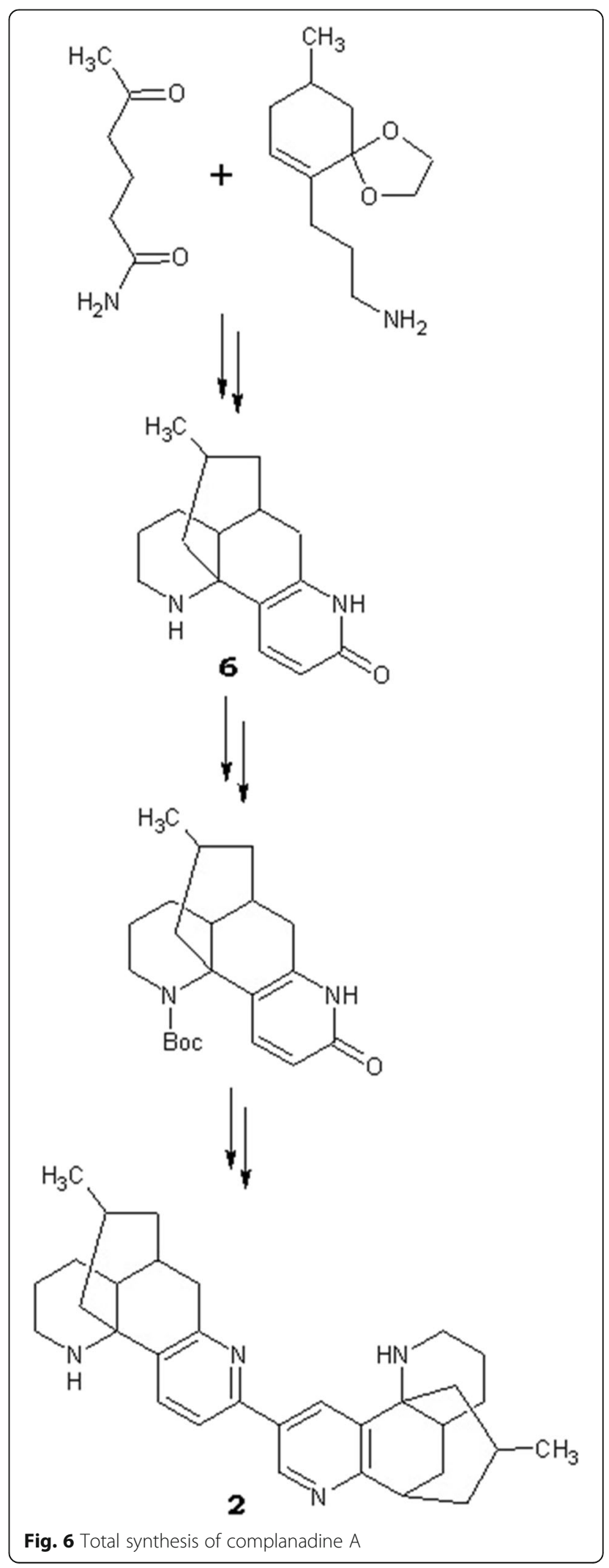


via the Wagner-Meerwein rearrangement (1,2-alkyl shift) followed by a series of dehydration and oxidation; or could be directly generated from a phlegmarine-type precursor by forming a new linkage between $\mathrm{C}-4$ and $\mathrm{C}-14$ forming the novel [6/7/6/6]-tetracyclic skeleton [25]. Lycocasuarines A, B, and Chave have also been described to be biosynthesized from huperzinine. Huperzinine, undergoes $C$ 8/C-15 oxidative cleavage to form the intermediate which can spontaneously convert to its enol form. This enol intermediatecyclizes via an aldol reaction with the C-15 carbonyl groupto afford a C-8 aldehyde intermediate, which finally reduces to Lycocasuarine A [27] (Fig. 4). Lycocasuarine I was reported to be biosynthesized from huperzinine by subsequent oxidative cleavage and $C_{11}$ reduction [31]. Recently, considering the therapeutic effects of Lycopodiaceae and Huperziaceaeare plants and alkaloids isolated from them, Chen et al. 2020 discovered the lycopodium alkaloids biosynthesis-related genes and genetic markers in L. casuarinoides stem and pin-like leaves transcriptome. They assembled 124,524 unigenes using $16.43 \mathrm{~Gb}$ clean data represented by 109 million RNA sequencing reads, out of which 47,538 open reading frames (ORFs) were detected. Several enzyme genes including those for lysine decarboxylase (LDC), primary amine oxidase (PAO), malonyl-CoA decarboxylase, etc. were also identified using bioinformatics tools. About 64 putative cytochrome p450 (CYP) genes and 827 putative transcription factors were located as biosynthesis modifiers. In 13352 simple sequence repeats (SSRs), dinucleotide motifs AG/CT were the most abundant (50.1\%) [40].

\section{Marketed preparations of Lycopodium species}

Mostly, club mosses, mainly, Lycopodium clavatum is administered by oral route. Club moss powder is being

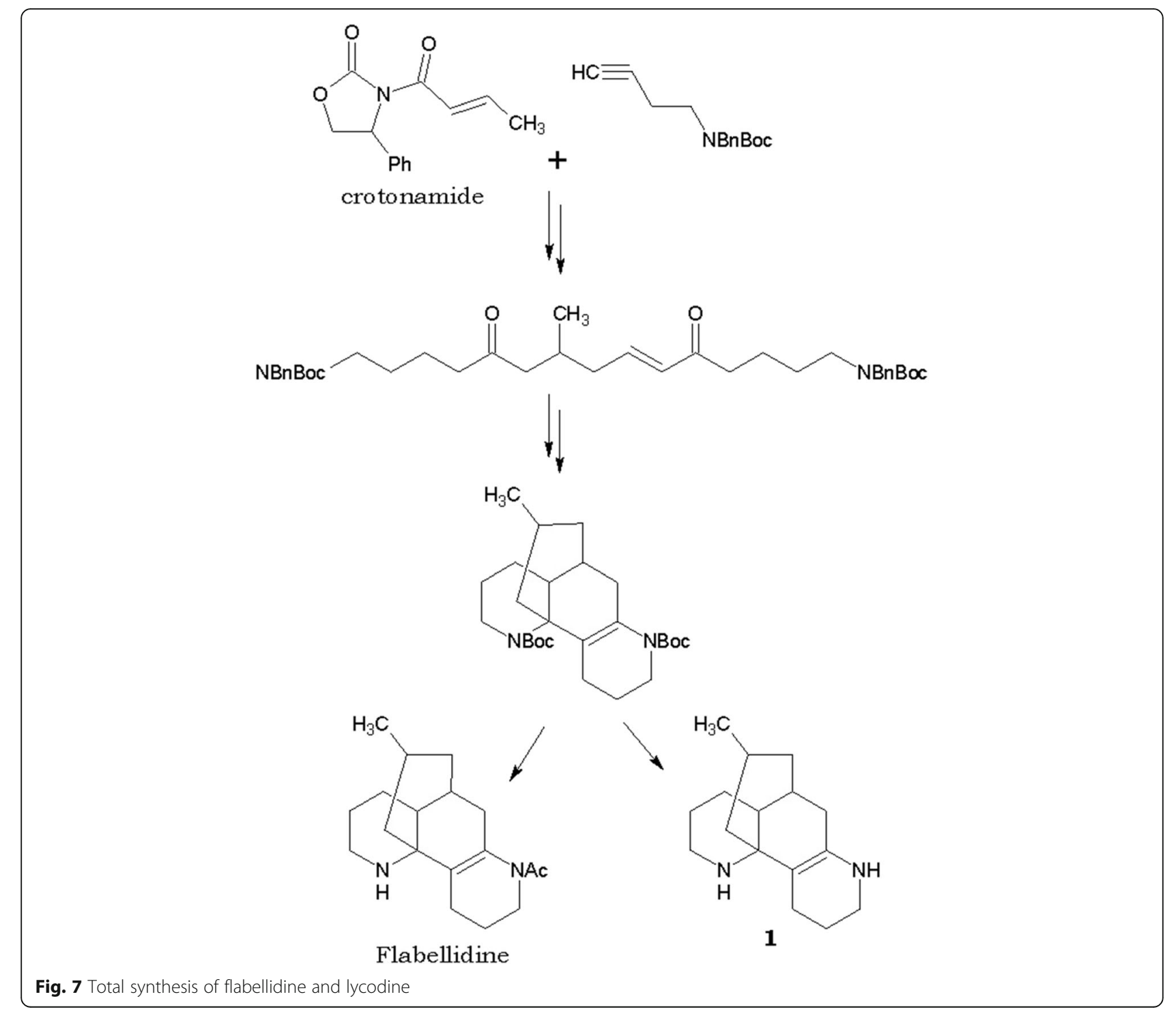


sold in the form of tea bags by Terravita Tincture of club moss, sold by HerbalTerra, USA, and Hawaii Pharm Llc, Honolulu, USA, are the alcoholic preparations. Terravita sells L. clavatum in form of powder as well as capsules (each $450 \mathrm{mg}$ of L. clavatum powder). Club moss glycerite liquid extract of L. clavatum has been made available by Terravita in various flavors like vanilla, chocolate, mint, or strawberry. New Zealand made Lycopodium liquid and is sold by NaturoPharm. Homeopathic formulation, liquid dilutions with $L$. clavatum, has been made available by SBL Pvt. Ltd. ADEL L. clavatum dilution $200 \mathrm{CH}$ have been launched by Adel Pekana, Germany. Apart from all these oral formulations, L. clavatum material is available for topical application through the formulation cream, with brand name, Bianca rosa.

\section{Total synthesis of newly isolated lycodine-type} Lycopodium alkaloids

Since 2000, several lycodine type lycopodium alkaloids have been isolated. But only few of them have been reported to be got totally synthesized in laboratory. Lycodine as a basic skeleton was synthesized earlier but in 2010, Tsukano et al. explained its concise synthetic attempt [41]. Here, triisopropylsilyl protected methyl 3-hydroxypicolinate was first converted to intermediate $\alpha, \beta$-unsaturated ester which was dienophile reacted with diene, to form DielsAlder product. It is on triflation, formed tetracyclic intermediate which on several reactions, converted to lycodine (Fig. 5).

Fischer and Sarpong, 2010 described the synthesis of (+)-Complanadine A [42]. Initially, enamide underwent hydrolysis to form enol tautomer ofketoamide, which in turn reacts with oxygen-sensitive $\alpha, \beta$-unsaturated imineto yield $\mathrm{N}$-desmethyl $\alpha$-obscurine, via series of cyclizations. Its Boc protection (en route) gave Boc-protected lycodine, which got converted to boronic ester. It was then by reaction with triflate, formed (+)-Complanadine A (Fig. 6).

Although biosynthesis of lycodine alkaloids is a bit complex to determine, Azuma et al. 2014 got inspired from biogenetic pathways to make flabellidine and lycodine successful total synthesis attempt [43]. They started with Hosomi-Sakuraiallylation of crotonamide and then other reactions to get linear precursor. Further, it formed tetracyclic lycodine skeleton which on debenzylation and simultaneous Boc protection to give easily separable di-Boc compounds. The removal of Boc groups of its amines and the chemoselective acetylationgave $(+)$-flabellidine exclusively, which after the selective oxidation of the A-ring furnished (-)-lycodine (Fig. 7).
Fu et al. 2015 initiated the synthesis of $\alpha$-obscurine, $\mathrm{N}$-desmethyl- $\alpha$-obscurine, $\beta$-obscurine, and $\mathrm{N}$-desmethyl$\beta$-obscurine using pulegone, which undergoes BuchwaldHartwig coupling, the Heck cyclization reactions, diastereoselective hydrogenation to form characteristic $\mathrm{A} / \mathrm{B} / \mathrm{C}$ ring system prior to the construction of the D-ring (Fig. 8) [44].

Recently, Burtea et al. 2019 started synthesis of (-)-Himeradine A by Sonogashira coupling on starting compound 2-bromo-4-methyl pyridine [45]. After 5 steps of additional several carbons, formed alkene derivative of N-Boc [N-(tert-Butoxycarbonyl)] piperidine, which in presence of Hoveyda-Grubbs 2nd generation catalyst, formed its hydroxyl derivative. Then, by catalyst-controlled Overman rearrangement,

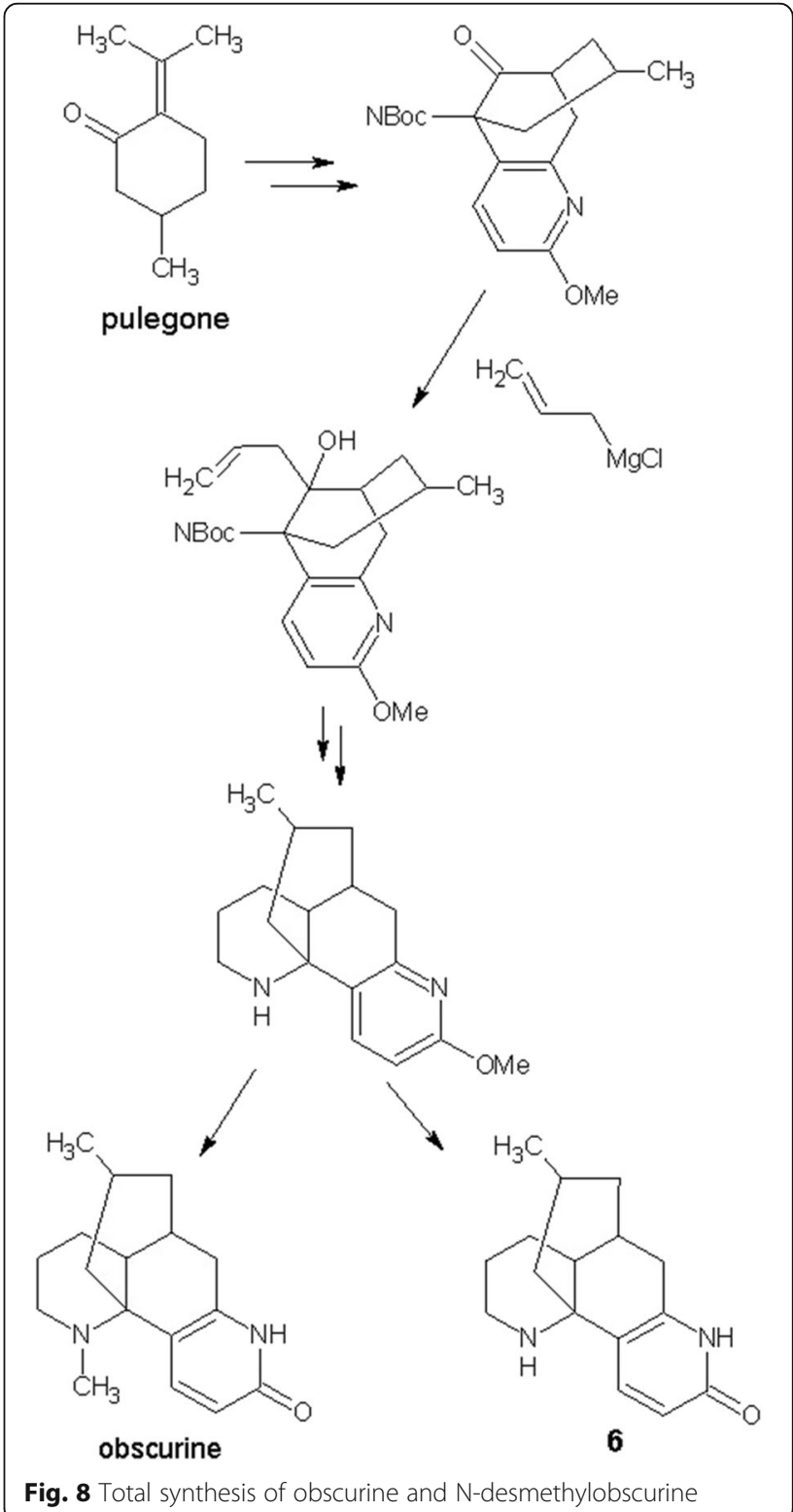




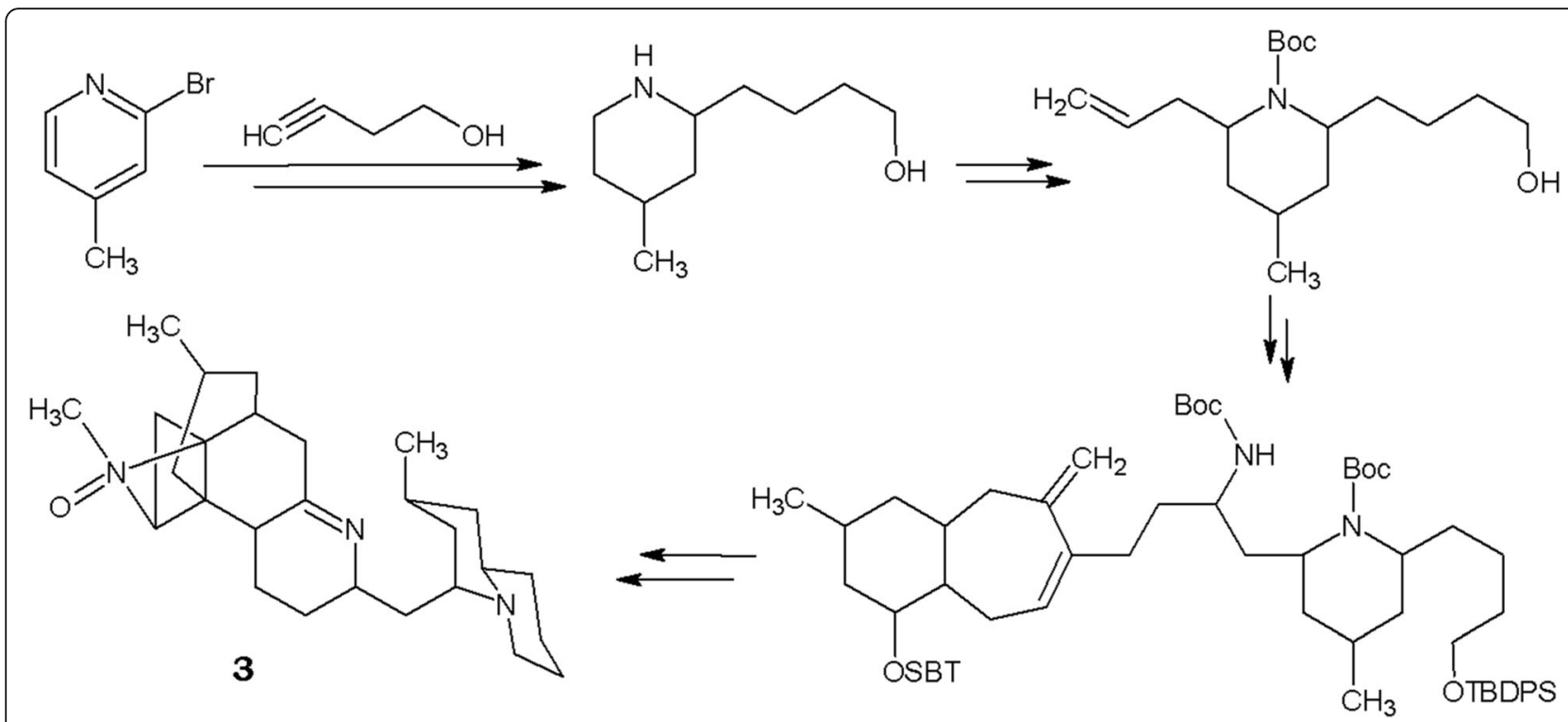

Fig. 9 Total synthesis of Himeradine A

trichloroacetamide derivative is formed, which in presence of iridium photocatalyst, generated $\alpha$-amino radical that underwent a stereoselective 1,4-addition to form enone derivative. Further by transannular Mannichcascade and cyclization; (-)-Himeradine A with 4 rings got synthesized in one reaction flask (Fig. 9).

\section{Conclusion}

Most of the lycodine-type alkaloids have AChE inhibitory activity with varying potency and thereby used in treatment of various diseases. Since 2000, more than 40 lycodine-type alkaloids have been reported to be isolated from different Lycopodiaceae or Huperziaceae plants. Researchers have also elucidated the plausible biogenetic pathways. Their structure-activity relationship revealed the potency with respect to structural variations. Few of these newly isolated alkaloids have been tried for total asymmetric laboratory synthesis. In the future, structures of these newly isolated compounds could be used to determine enzyme inhibition or protein binding through molecular docking approach, thereby necessary changes in existing structures could be made and accordingly, the new derivatives of lycodine structures could be synthesized. This will be helpful in increasing potency and reducing side effects, if any.

\section{Abbreviations}

AChE: Acetylcholinesterase; ATCl: Acetylthio choline iodide; DTNB: 5,5dithiobis (2-nitrobenzoic acid); RBC: Red blood cells

\section{Acknowledgements}

The authors of this manuscript are thankful to Dr. (Mrs.) Anagha M. Joshi, Principal, SCES's Indira College of Pharmacy, Pune, for her encouragement and also for providing internet and library facilities at the college premises to access the articles and books to carry out this review.

Author's contributions

SPP selected the topic to be made review upon; collected necessary data/ research articles already published on the topic; drawn the structures; wrote manuscript with respect to recently isolated Lycodine alkaloids, their structure-activity relationship, biosynthetic pathways, and total synthesis; and also involved in critical thinking about entire write-up. The author read and approved the manuscript.

Funding

Not applicable

Availability of data and materials

All data and material are available upon request.

Ethics approval and consent to participate

Not applicable

Consent for publication

Not applicable

\section{Competing interests}

All authors declare that they have no competing interest.

Received: 17 February 2020 Accepted: 7 September 2020

Published online: 24 November 2020

\section{References}

1. Hirasawa Y, Kobayashi J, Morita H (2009) The lycopodium alkaloids. Heterocycles 77:679-729. https://doi.org/10.3987/REV-08-SR(F)6

2. Kobayashi J, Morita H 2004 In The alkaloids; Cordell, G. A., Ed.; vol 61. Academic Press: New Yorkdoi: 10.1016/S1099-4831(05)61001-2

3. Hemscheidt T, Spenser ID (1996) A Classical paradigm of alkaloid biogenesis revisited: acetonedicarboxylic acid as a biosynthetic precursor of lycopodine. J Am ChemSoc 118:1799-1800. https://doi.org/10.1021/ja953735q

4. Liu JS, Zhu YL, Yu CM, Zhou YZ, Han YY, Wu FW, Qi BF (1986) The structures of huperzine $A$ and $B$, two new alkaloids exhibiting marked anticholinesterase activity. Can J Chem 64:837-839. https://doi.org/10.1139/v86-137

5. Ayer WA (1991) The Lycopodium alkaloids. Nat Prod Rep 8:455-663. https://doi.org/10.1039/NP9910800455 
6. Bödeker K (1881) Lycopodin, das ersteAlkaloïd der Gefässkryptogamen Justus Liebigs Ann Chem 208:363. https://doi.org/10.1002/jlac.18812080308

7. Achmatowicz O. and Uzieblo W., 1938, Alkaloids of lycopodium (Lycopodium clavatum L.).Rocz. Chem. 18, 88-95 (in English 94-95).

8. Rothmaler W., FeddesRepertoriumSpecierumNovarum, 1944, 54, 55-82. https://doi.org/10.1002/fedr.19440540106

9. Cheng YS., Lu CZ., Ying ZL., Ni WY., Zhang CL., Sang GW. Chinese J. New Drugs Clin. Remedies, 1986, 5, 197-199.

10. Liu JS, Yu CM, Zhou YZ, Han YY, Wu FW, Qi BF, Zhu YL (1986a)Chemical Study of Huperzine A and Huperzine B. ActaChim Sin. (Engl. Ed.) 44: 1035-1040.

11. Liu JS, Zhu YL, Yu CM, Zhou YZ, Han YY, Wu FW, Qi BF (1986b) The structures of huperzine A and B,' two new alkaloids exhibiting marked anticholinesterase activity. Can J Chem. 64:837-839. https://doi.org/10.1139/ v86-137

12. College JNM (1985) The dictionary of traditional Chinese medicine. Shanghai Sci-Tech Press, Shanghai

13. Ma X, Gang DR (2008) In vitro production of huperzine A, a promising drug candidate for Alzheimer's disease. Phytochem 69:2022-2028. https://doi.org/ 10.1016/j.phytochem.2008.04.017

14. Kobayashi J, Hirasawa Y, Yoshida N, Morita H (2000) Complanadine A, a new dimeric alkaloid from Lycopodium complanatum. Tetrahedron Lett. 41:90699073. https://doi.org/10.1016/S0040-4039(00)01630-0

15. Morita H, Hirasawa Y, Kobayashi J (2003) Himeradine A, a novel C27N3-type alkaloid from Lycopodium chinense. J Org Chem. 68:4563-4566. https://doi. org/10.1021/jo034294t

16. Yin S, Fan CQ, Wang XN, Yue JM (2006) Lycodine-type alkaloids fromLycopodium casuarinoides. Helvetica chimicaacta. 89(1) doi:10.10.1002/ hlca.200690006

17. Katakawa K, Kogure N, Kitajima M, Takayama H (2009) A New Lycopodium Alkaloid, Lycoposerramine-R, with a Novel Skeleton and Three New Fawcettimine-Related Alkaloids from Lycopodium serratum. Helvetica ChimicaActa. 92:445-452. https://doi.org/10.1002/hlca.200800327

18. Liu F, Wu XD, He J, Deng X, Peng LY, Luo HR, Zhao QS (2013) Casuarines A and B. Lycopodium alkaloids from Lycopodium casuarinoides. Tetrahedron Lett. 54:4555-4557. https://doi.org/10.1016/j.tetlet.2013.06.083

19. Vajjelo MG, Ortega MG, Cabrera JL, Agnese AM (2013) N-demethylsauroxine, a novel lycodine group alkaloid from Huperziasaururus. Tetrahedron Lett. doi:10.016/j.tetlet.2013.07.068

20. Wu J, Wang H, Ma Y, Jiang J, Zhan R, Chen Y (2014) Isolation of a new lycodine alkaloid from Lycopodium japonicum. Nat Prod Res. https://doi.org/ 10.1080/14786419.2014.984184

21. Jiang WW, Liu F, Gao X, He J, Cheng X, Peng LY, Wu XD, Zhao QS (2014) Huperserines A-E, Lycopodium alkaloids from Huperzia serrata. Fitoterapia 99:72-77. https://doi.org/10.1016/j.fitote.2014.09.005

22. Thorroad S, Worawittayanont $P$, Khunnawutmanotham N, Chimnoi N, Jumruksa A, Ruchirawat S, Thasana N (2014) Three new Lycopodium alkaloids from Huperziacarinata and Huperziasquarrosa. Tetrahedron 70 8017-8022. https://doi.org/10.1016/j.tet.2014.08.042

23. ZhangDB CJJ, SongQY ZL, Gao K (2014) Lycodine-type alkaloids from Lycopodiastrumcasuarinoides and their acetylcholinesterase inhibitory activity. Molecules 19(7):9999-10010. https://doi.org/10.3390/ molecules 19079999

24. WuJ WHQ, Ma YF, Jiang JH, Zhan R, Chen YG (2015) Isolation of a new lycodine alkaloid from Lycopodium japonicum. Nat Prod Res 29:735-738. https://doi.org/10.1080/14786419.2014.984184

25. Meng WJ, Xiong J, Wang WX, Zhang HY, Zeng H, Hu JF (2016) Phlefargesiine A, a C16N2 Lycopodium alkaloid with an unprecedented [6/ 7/6/6]-tetracyclic skeleton from Phlegmariurusfargesii. Tetrahedron Lett. 57: 3218-3221. https://doi.org/10.1016/j.tetlet.2016.06.050

26. Liu YC, Su J, Wu XD, Zhang ZJ, Fan M, Zhu QF, He J, Li XN, Peng LY, Cheng X, Zhao QS (2016) Five new Lycopodium alkaloids from the aerial parts of Phlegmariurushenryi. Fitoterapia 115:148-154. https://doi.org/10.1016/j.fitote. 2016.10.005

27. Wang LL, Zhu XL ZZB, Yuan FY, Miyamoto T, Pan K (2017) Lycocasuarines A-C. Lycopodium alkaloids from Lycopodiastrumcasuarinoides. Tetrahedron Lett. 58:4827-4831. https://doi.org/10.1016/j.tetlet.2017.11.019

28. Tang Y, Xiong J, Zou Y, Wang W, Huang C, Zhang HY, Hu JF (2017) Annotinolide $\mathrm{F}$ and lycoannotines A-I, further Lycopodium alkaloids from Lycopodium annotinum. Phytochem. 143:1-11. https://doi.org/10.1016/j. phytochem.2017.07.003
29. Xiong J, Meng WJ, Zhang HY, Zou Y, Wang WX, Wang XY, Yang QL, Osman EEA, Hu JF (2019) Lycofargesiines A-F, further Lycopodium alkaloids from the club moss Huperziafargesii. Phytochem 162:183-192. https://doi.org/10. 1016/j.phytochem.2019.03.015

30. Vallejo MG, Corzo ME, Ortega MG Agnese AM(2018)12a-hydroxy-Ndemethyl-sauroxine, a lycodane type alkaloid from Phlegmariurussaururus. Nat ProdRes. https://doi.org/10.1080/14786419.2018.1560287

31. Zhu XL, Wang LL, Shi ZH, Xia D, Zhou ZB, Pan K (2019) Lycocasuarines I-Q, new Lycopodium alkaloids isolated from Lycopodiastrumcasuarinoides. Fitoterapia 134:474-480. https://doi.org/10.1016/jfitote.2019.03.027

32. Yeap JSY, Lim KL, Yong KT, Lim SH, Kam TS, Low YY (2019) Lycopodium Alkaloids: Lycoplatyrine A, an Unusual Lycodine- Piperidine Adduct from Lycopodium platyrhizomaand the Absolute Configurations of Lycoplanine D and Lycogladine H. J Nat Prod. https://doi.org/10.1021/acs.jnatprod.8b00754

33. Canham SM, France DJ, Overman LE (2010) Total synthesis of (+)-sieboldine A. J AmChem Soc 132:7876-7877. https://doi.org/10.1021/ja103666n

34. Nakamura Y, Burke AM, Kotani S, Ziller JW, Rychnovsky SD (2010) Synthesis of (-)-lycoperine A. Org Lett 12:72-75. https://doi.org/10.1055/s-0029-1219713

35. Yuan C, Chang CT, Axelrod A, Siegel D (2010) Synthesis of (+)-complanadine a, an inducer of neurotrophic factor excretion. J Am Chem Soc. 132:59245925. https://doi.org/10.1021/ja101956x

36. Ellman GL, Courtney KD, Andres V, Featherstone RM (1961) A new and rapidcolorimetric determination of acetylcholinesterase activity. Biochem. Pharmacol 7:88-95. https://doi.org/10.1016/0006-2952(61)90145-9

37. Vallejo MG, Corzo ME, Ortega MG, Agnese AM (2018) 12a-hydroxy-Ndemethyl-sauroxine, a lycodane type alkaloid from Phlegmariurussaururus. Nat Prod Res. https://doi.org/10.1080/14786419.2018.1560287

38. Li P, Huang W, Zhuo J, Guo Z, Cao W, Li Xu L, Ma L, Chen ZE, Kennelly EJ, Wu SB, Long C (2015) Seven new Lycopodium alkaloids from the aerial parts of Phlegmariurussquarrosus. Tetrahedron 71:5308-5314. https://doi.org/ 10.1016/j.tet.2015.06.012

39. Nguyen HT, Doan HT, Ho DV, Pham KY, Raal A, Morita H (2018) Huperphlegmines $\mathrm{A}$ and $\mathrm{B}$, two novel Lycopodium alkaloids with an unprecedented skeleton from Huperziaphlegmaria, and their acetylcholinesterase inhibitory activities. Fitoterapia 129:267-271. https://doi.org/10.1016/j.fitote.2018.07.016

40. Chen G, Lin Q, Zeng L, Zou Y (2020) Mining lycodine-type alkaloid biosynthetic genes and genetic markers from transcriptome of Lycopodiastrum casuarinoides. Chinese Herbal Medicines 12:133-141. https://doi.org/10.1016/j.chmed.2020.03.001

41. Tsukano C, Zhao L, Takemoto Y, Hirama M (2010) Concise total synthesis of lycodine. Eur J Org Chem.:4198-4200. https://doi.org/10.1002/ejoc. 201000667

42. Fischer DF, Sarpong R (2010) Total synthesis of (+)-complanadine A using an iridium-catalyzed pyridine C-H functionalization. J Am Chem Soc. 132(17):5926-5927. https://doi.org/10.1021/ja101893b

43. Azuma M, Yoshikawa T, Kogure N, Kitajima M, Takayama H (2014) Biogenetically inspired total syntheses of lycopodium alkaloids, (+)-flabellidine and (-)-lycodine. J Am Chem Soc. https://doi.org/10.1021/ja507016g

44. Fu JG, Xu GQ, Ding R, Lin GQ, Sun BF (2015) Asymmetric total synthesis of Lycopodium alkaloids a-obscurine, $\mathrm{N}$-desmethyl-a-obscurine, $\beta$-obscurine and N-desmethyl-ß-obscurine. Org Chem Front. https://doi.org/10.1039/ c5qo00355e

45. Burtea A, DeForest J, Li X, Rychnovsky SD (2019) Total Synthesis of (-)-Himeradine A. Angew Chem. 58:1-6. https://doi.org/10.1002/anie.201910129

\section{Publisher's Note}

Springer Nature remains neutral with regard to jurisdictional claims in published maps and institutional affiliations. 